\title{
KULTURA INTELEKTUALNA I DUCHOWA DOMINIKANÓW WILEŃSKICH W ŚWIETLE INWENTARZA BIBLIOTEKI Z I POLOWY XVII WIEKU
}

\begin{abstract}
Streszczenie
Inwentarz biblioteki dominikanów wileńskich z 1. połowy XVII wieku rejestruje 506 pozycji wydawniczych. Są wśród nich druki opublikowane w XV, XVI i w niewielkiej liczbie w XVII stuleciu. Wydrukowane zostały przede wszystkim przez oficyny zagraniczne: włoskie, francuskie, niemieckie, niderlandzkie i szwajcarskie. Pod względem treściowym reprezentują wszystkie ówczesne obszary wiedzy ludzkiej, a ich liczebność w poszczególnych działach odzwierciedla zapotrzebowanie przez dominikanów wileńskich na określone piśmiennictwo, które pozwalało im właściwie wypełniać zadania wobec własnego zgromadzenia, klasztoru i otoczenia zewnętrznego.

Słowa kluczowe: książka; biblioteka; inwentarz; dominikanie; Wilno; XVII wiek
\end{abstract}

Książka jako wytwór kultury i narzędzie cywilizacji, utrwalająca i przekazująca w czasie i przestrzeni treści duchowe i materialne, należy do istotniejszych źródeł poznania dorobku całych społeczeństw, ich poszczególnych grup oraz jednostek. Świat książek w trakcie swoich dziejów doświadczał takich samych skutków różnych wydarzeń jak i inne obszary życia gospodarczego, społecznego czy nawet politycznego. W wyniku wielu, niesprzyjających zachowaniu dawnych przekazów myśli ludzkiej okoliczności, do czasów współczesnych zachowała się tylko niewielka część wytworów dawnej produkcji książkowej i źródeł informacji o nich. Umieszczona pośród innych zjawisk kultury książka daje szansę głębszego poznania różnych form życia indywidualnego i społecznego, w tym również kultury intelektualnej i duchowej określonych środowisk, do których należą też

\footnotetext{
*Maria Juda - prof. historii; Instytut Historii, Uniwersytet Marii Curie-Skłodowskiej w Lublinie; e-mail: dyrekt@biblio.umcs.lublin.pl

https://orcid.org/0000-0001-7557-1850
} 
wspólnoty zakonne. Pozostałe po nich, zazwyczaj fragmenty zasobów bibliotecznych, inwentarze czy spisy książek stanowią niezwykle istotne źródło do badań nad kulturą życia zakonnego i oddziaływania tego środowiska na otoczenie zewnętrzne ${ }^{1}$.

Prowadzone od wielu lat kwerendy archiwalne i biblioteczne doprowadziły do odkrycia znaczącej liczby tego rodzaju źródeł bibliologicznych, w tym również klasztorów zakonu kaznodziejskiego ${ }^{2}$. Poddawany analizie inwentarz księgozbioru wileńskich dominikanów Libri Conventus Vilnensis ${ }^{3}$ sporządzony został najprawdopodobniej w 1. połowie XVII wieku. Na pewno powstał po 1617 r., a wskazuje na to zarejestrowana edycja dzieła Jana Dunsa Szkota ${ }^{4}$. Najstarszą książką są Listy św. Cypriana 5 . Spisany został jedną ręką włoską bastardą humanistyczną, używaną w różnego rodzaju kancelariach na ziemiach polskich od schyłku XVI do początku XVIII stulecia ${ }^{6}$. Służył zapewne do ustalenia stanu majątkowego wileńskiego klasztoru w zakresie posiadanych zbiorów bibliotecznych, poprzez ustalenie przede wszystkim liczby woluminów. Cel ten thumaczy bardzo uproszczony zapis inwentarzowy, w wielu przypadkach niepozwalający na identyfikację bibliograficzną dzieła. Poza imieniem i nazwiskiem autora oraz zazwyczaj skróconym tytułem nie zawiera on żadnych innych danych o książce. Ponadto znaczną liczbę opisów stanowi jedynie tytuł dzieła (często skrócony lub zmodyfikowany), zdarzają się też opisy podające tylko nazwisko autora bez wyszczególnienia tytułu. W wielu przypadkach widnieje tylko określenie opera lub opusculum. W inwentarzu brakuje informacji o roku i miejscu wydania oraz formacie zarejestrowanych w nim druków. Ówczesny księgozbiór dominikański zawierał zapewne dzieła drukowane, ale nie można wykluczyć, że mogły się w nim znaleźć także w niewielkiej liczbie rękopisy. Ze względu na brak odpowiednich danych trudno jednak je wyodrębnić. Opisy inwentarzowe nie zostały prawdopodobnie sporządzone $\mathrm{z}$ autopsji, wskazują na to błędy w zapisie wielu nazwisk autorów czy tytułów dzieł, które mogły wynikać z przesłyszenia. Wszystkie zapisy

${ }^{1}$ Zob. J. Skoczek, Inwentarze biblioteczne jako źródto do dziejów kultury Polski epoki Odrodzenia, „Sprawozdania Poznańskiego Towarzystwa Przyjaciół Nauk”, 21 (1957) s. 267-270; K. Warda, Inwentarze bibliotek klasztornych jako źródto do dziejów ksiazzki polskiej w XIX w., „Studia o Książce", 15 (1985) s. 115-123; B. Bieńkowska, Inwentarze księgozbiorów prywatnych jako źródto do badań nad dziejami czytelnictwa, „Studia o Książce”, 18 (1989) s. 65-75; K. Migoń, Dawne katalogi biblioteczne jako źródło wiedzy o kulturze książki, „Roczniki Biblioteczne”, 49 (2005) s. 301-310. O kulturze książki, zob. Migoń, Bibliologia - nauka o kulturze ksiązki, w: Encyklopedia książki, red. A. Żbikowska-Migoń i M. Skalska-Zlat, t. 1, Eseje·A-J, Wrocław 2017, s. 23-32.

${ }^{2}$ Zob., M. Miławicki, Inwentarze i spisy bibliotek klasztorów dominikańskich skasowanych w guberniach zachodnich Cesarstwa Rosyjskiego w XIX w. Stan źródet i miejsce ich przechowywania, „Hereditas Monasteriorum”, 1 (2012) s. 141-172, tam również bogata literatura przedmiotu.

${ }^{3}$ Archiwum OO. Dominikanów w Krakowie (dalej: ADKr), sygn. I.c.III 76/252. Teka wileńska.

${ }^{4}$ Johannes Duns Scotus, Io. Dunst Scott .. In VIII. lib. Phisicorum Aristotelis quaestiones, et expositio, Venetiis, Apud Joannem Guerilium, 1617.

${ }^{5}$ Incipiunt epistol[ae] Cecylii Cypriani ad Cornelium Papam, [Venetiis], Vendelinus de Spira, [1471] lub Romae, Conradus Sweynheym, Arnoldus Pannartz, 1471.

${ }^{6}$ J. Słowiński, Rozwój pisma łacińskiego w Polsce w XVI-XVIII wieku. Studium paleograficzne, Lublin 1992, s. 104-116. 
- z jednym tylko wyjątkiem - sporządzone zostały w języku łacińskim. Kolejność spisanych książek nie jest - jak to często bywa w tego rodzaju źródłach - uporządkowana według działów, w jakich były ustawione na półkach bibliotecznych, ale jest dowolna. Rejestruje on w pewnych miejscach w jednym ciągu po kilka lub kilkanaście pozycji, które można by przypisać do jakiegoś konkretnego działu, ale nawet w takich okolicznościach nie widać konsekwencji, są one bowiem poprzeplatane opisami dzieł o odmiennej treści. Tylko w jednym przypadku uwidacznia się zgrupowany spis kilku pozycji jednego autora i dotyczy to rejestracji dzieł św. Tomasza z Akwinu. Przeważnie jednak opisy, nawet tych samych tekstów jednego autora, widnieją w różnych miejscach inwentarza. Można zatem przyjąć, że nie zastosowano w nim żadnych stałych kryteriów w porządkowaniu opisów, co mogło wynikać z faktu, że albo księgozbiór nie był wówczas uporządkowany, albo w spisie znalazły się książki, które czekały na uporządkowanie lub też znajdowały się w różnych pomieszczeniach klasztornych.

$\mathrm{Na}$ zarejestrowanych 506 pozycji wydawniczych składają się dzieła o różnej treści, stanowiące dorobek autorów doby starożytnej, wczesnego, pełnego i późnego średniowiecza oraz epoki wczesnonowożytnej. Identyfikacja bibliograficzna, przeprowadzona przede wszystkim w oparciu o Worldcat.org: The World's Largest Library Catalog ${ }^{7}$ pozwoliła na uzyskanie danych dotyczących poprawnego brzmienia imion i nazwisk autorów, tytułów, wydawców, miejsca i roku edycji w odniesieniu do 435 wymienionych w spisie dzieł w 516 woluminach. Nie zostało zidentyfikowanych 71. Do piętnastowiecznych wytworów sztuki typograficznej należy 92, do szesnastowiecznych 337, a do siedemnastowiecznych sześć. Dziełem oficyn zagranicznych jest 413, pozostałe 22 można przypisać działającym na ziemiach Rzeczypospolitej Obojga Narodów. Z obcych ośrodków sztuki drukarskiej na czoło wysuwają się Paryż, Lyon i Wenecja oraz niewiele im ustępująca Kolonia. Za nimi plasuje się szwajcarska Bazylea, a następnie Strasburg, Antwerpia i Norymberga. W pierwszych wiekach istnienia drukarstwa ośrodki te współzawodniczyły ze sobą w opanowaniu rynku wydawniczo-księgarskiego. Zaliczały się one również do czołowych centrów europejskiego handlu książką katolicką. Wyraźne faworyzowanie włoskich ośrodków wydawniczych przez dominikanów, także wileńskich, mogło wynikać z faktu, że kapituły generalne tego zgromadzenia od połowy XV wieku odbywały się przeważnie w Italii, gdzie polscy wysłannicy mogli nabyć książki i przywozić je do kraju. Z kolei Francja z Paryżem była tradycyjnym ośrodkiem studiów otwartych na potrzeby całego zakonu. Dominacja Kolonii w XVI wieku wynikała zapewne z tego, że w tym okresie stała się ona głównym centrum handlu książką katolicką w Niemczech, z którym polskie księgarstwo utrzymywało ożywione kontakty. Dziełem krakowskich oficyn jest 19 pozycji, wileńskich dwie, a jedna pochodzi z Królewca.

Aby pełniej poznać uwzględniony w inwentarzu zasób biblioteki wileńskich dominikanów pod kątem jej zawartości treściowej, należy pogrupować poszczególne zapisy według ich tematyki. Wydaje się, że przydatne w tym względzie będzie posłużenie się typowym dla dawnych księgozbiorów klasztornych schema-

\footnotetext{
${ }^{7}$ https://www.worldcat.org (dostęp: 01.05 - 31.11.2019).
} 
tem klasyfikacyjnym ${ }^{8}$, który pozwoli nie tylko na ustalenie typowości wileńskiej książnicy, ale także na porównanie jej zasobu z bibliotekami innych klasztorów dominikańskich, w których taki podział z mniejszymi lub większymi odchyleniami na ogół stosowano.

Niemal w każdym księgozbiorze historycznym układ książek otwierał dział zawierający Pismo Święte i komentarze do niego. Inwentarz odnotowuje jeden egzemplarz Biblii określony jako Biblia Sacra. Chociaż wymieniony jest na pierwszym miejscu, to jednak zastanawia fakt, że jest to pozycja występująca w jednym egzemplarzu, podczas gdy ówczesne biblioteki klasztorne posiadały ich kilka a nawet kilkanaście. Wykazuje jednak kilka pozycji związanych z Pismem Świętym, a wśród nich Liber moralitatum in Bibliae, Prologus in Biblia oraz Index utriusque Testamenti. Są też konkordancje, w tym Concordantiae Bibliorum prawdopodobnie autorstwa dominikanina - kardynała Hugona z Santo Caro, w której zastosowano podział Biblii na wiersze ${ }^{9}$ oraz trzy egzemplarze Concordantia maiores Bibliae Veteri et Novi Testamenti innego autora z zakonu kaznodziejskiego Conrada z Halberstadt ${ }^{10}$.

Z Pismem Świętym związane są dzieła mające na celu wydobycie sensu tekstu biblijnego czyli egzegezę. Pisma egzegetyczne stanowią większą liczebnie grupę niż Biblia i konkordancje. Spośród wielu komentatorów Starego i Nowego Testamentu należy wymienić franciszkańskiego teologa i egzegetę Mikołaja z Liry - autora Postillae super Psalterium, którego postylle opierały się na bogatej tradycji patrystycznej i podbudowane znajomością tekstu hebrajskiego uważane były przez długi czas za najlepszy komentarz nowożytny do tego stopnia, że tylko w latach 1471-1600 osiągnęły ponad 100 wydań ${ }^{11}$. W bibliotece znajdowały się również dwa egzemplarze Postillae sive enarrationes in Evangelia franciszkanina, znanego teologa, polemisty, kaznodziei i egzegety Franciszka Polygranusa ${ }^{12}$ oraz Postilla Antoniego z Königstein ${ }^{13}$.

Było też wiele komentarzy do różnych ksiąg Starego Testamentu, a wśród nich Explanationes in Psalmos św. Augustyna, zawierające objaśnienie wszyst-

${ }^{8}$ Np. K. Zawadzka, Biblioteka klasztoru dominikanów we Wroctawiu(1226-1810), w: Studia nad historią dominikanów w Polsce, red. J. Kłoczowski, t. 2, Wrocław 1975, s. 290-362; I. Szostek, Biblioteka dominikanów lwowskich w świetle katalogu z roku 1776, w: Studia nad historia dominikanów $w$ Polsce, red. J. Kłoczowski, t. 2, Wrocław 1975, s. 409-446; J. A. Kosiński, Biblioteka konwentu dominikanów w Sieradzu na przełomie XVI i XVII wieku, w: dominikanów w Polsce, red. J. Kłoczowski, t. 2, Wrocław 1975, s. 392-404; R. Świętochowski, Biblioteka oo. Dominikanów w Krakowie, „Archiwa, Biblioteki i Muzea Kościelne” (dalej: ABMK), 33 (1976) s. 299-311; M.L. Niedziela, Charakterystyka biblioteki klasztoru Dominikanów w Borku Starym w XVII i XVIII wieku, „Śląski Kwartalnik Historyczny. Sobótka”, 51 (1996) s. 196-203; J. Długosz, Biblioteka klasztoru karmelitów bosych w Wiśniczu (1630-1649), ABMK, 13 (1966) s. 132-162.

${ }^{9}$ S. Janeczek, Hugon ze Świętego Wiktora, w: Encyklopedia katolicka (dalej: EK), t. 6, red. J. Walkusz, Lublin 1993, kol. 1292.

${ }^{10}$ Lexikon für Theologie und Kirche, Bd. 3. Freiburg im Breisgau 1959, kol. 464.

${ }^{11}$ Encyklopedia Kościoła, red. F.L. Cross, E.A. Livingstone, t. 2, Warszawa 2004, s. 233; S. Szymik, Mikołaj z Liry, EK, t. 12, red. S. Wilk, Lublin 2008, kol. 1005-1006.

${ }^{12}$ Lexikon für Theologiae, t. 8, Freiburg Breisgau 1963, kol. 369-360.

${ }^{13}$ Lexikon für Theologiae, t. 1, Freiburg Breisgau 1957, kol. 674. 
kich psalmów w postaci popularnych homilii ${ }^{14}$, oparte na tym dziele Expositio psalmorum Kasjodora ${ }^{15}$ - wczesnochrześcijańskiego pisarza i organizatora naukowego życia zakonnego oraz Expositio in Ezechielem św. Grzegorza Wielkiego papieża, jednego z czterech wielkich doktorów Kościoła zachodniego ${ }^{16}$. Widnieją również liczne objaśnienia do Ewangelii i Listów Apostolskich, zarówno autorów średniowiecznych jak i wczesnonowożytnych. Greckich ojców Kościoła reprezentuje najwybitniejszy homileta Kościoła greckiego św. Jan Chryzostom doktor Kościoła i jego najsłynniejsze dzieło egzegetyczne - komentarz do Ewangelii św. Mateusza ${ }^{17}$. Nie zabrakło też homiletycznego komentarza do pierwszego Listu św. Jana Apostoła pióra św. Augustyna. Oprócz tego w dominikańskim księgozbiorze znaleźć można dzieła innych komentatorów, na czoło których wysuwają się: franciszkanin Jan Ferus - autor Postillae maiores totus anni, zawierającej komentarz do czerech Ewangelii ${ }^{18}$ oraz Jan Hoffmeister - słynny kaznodzieja i egzegeta, autor komentarza do Ewangelii św. Łukasza ${ }^{19}$. Wśród komentarzy ewangelicznych było również składające się $\mathrm{z}$ tekstów greckich i łacińskich ojców Kościoła dzieło św. Tomasza z Akwinu, znane pod tytułem Catena aurea oraz w trzech egzemplarzach Aurea Rosa super Ewangelia innego dominikanina Sylwestra z Priero ${ }^{20}$. W bibliotece konwentu Św. Ducha znajdowało się jeszcze wiele komentarzy do Listów św. Pawła autorstwa nie tylko wybitnych przedstawicieli własnego zgromadzenia - św. Tomasza z Akwinu, Tomasza de Vio, Wilhelma z Paryża, ale też przedstawicieli innych zakonów - benedyktyna Hajmona z Halberstadt, franciszkanina Antoniego z Königstein, uczonego kartuza Dionizego z Rikel i wielu innych. W sumie był to jeden z najobszerniejszych działów w księgozbiorze, zawierał bowiem 70 dzieł w 79 woluminach.

Dział obejmujący teksty ojców Kościoła i pisarzy okresu patrystycznego zawierał prace niemal wszystkich najwybitniejszych przedstawicieli tego nurtu. Najliczniej reprezentowane są pisma jednego z najbardziej oryginalnych i twórczych pisarzy chrześcijańskich doby starożytnej - św. Augustyna ${ }^{21}$. W księgozbiorze widnieją edycje zbiorowe - dziewięciotomowe Opera omnia i Opuscula plurimi oraz pojedyncze wydania De civitate Dei (dwa egzemplarze), De fide et symbolo, Canones, Liber epistolarum beati Augustini. Nie zabrakło spisu jego dzieł-Regestrum in libros divi Aurelii Augustini. Jest też trzytomowe wydanie prac jednego z czterech wielkich doktorów Kościoła zachodniego, autora pism dogmatycznych

${ }^{14}$ J. Misiurek, Augustyn, EK, t. 1, red. F. Gryglewicz, R. Łukaszyk, Z. Sułowski, Lublin 1973, kol. 1093; A. Trapé, Święty Augustyn - człowiek, duszpasterz, mistyk, Warszawa 1987.

${ }^{15}$ S. Longosz, Kasjodor, EK, t. 8, red. B. Migut, Lublin 2000, kol. 946-949.

${ }^{16}$ S. Rosik, Grzegorz I Wielki, EK, t. 6, red. J. Walkusz, Lublin 1993, kol. 324, 327.

${ }^{17}$ F. Drączkowski, Jan Chryzostom, EK, t. 7, red. S. Wielgus, Lublin 1997, kol. 799-769.

${ }^{18}$ Encyklopedia Kościelna, t. 5, red. M. Nowodworski, Warszawa 1874, s. 335.

${ }^{19}$ M. Daniluk, Hoffmeister Johann, EK, t. 6, red. J. Walkusz, Lublin 1993, kol. 1109.

${ }^{20}$ Lexikon für Theologiae, t. 8, kol. 735.

${ }^{21}$ J. Misiurek, Augustyn, EK, t. 1, red. F. Gryglewicz, R. Łukaszyk, Z. Sułowski, Lublin 1973, kol. 1087-1095. 
i egzegetycznych św. Ambrożego ${ }^{22}$ oraz dwa egzemplarze Listów św. Hieronima, w których ukazane zostało całe bogactwo duchowości Wschodu ${ }^{23}$. Są również Listy św. Cypriana, z których korzystali kanoniści do redagowania ustaw prawa kościelnego ${ }^{24}$. Wspólnie $\mathrm{z}$ autorem wielu prac apologetycznych i moralistycznych Tertulianem ${ }^{25}$ uchodzi on za twórcę łaciny kościelnej. Księgozbiór był też dobrze zaopatrzony w teksty pozostałych ojców Kościoła, a przede wszystkim patrona kaznodziejów św. Jana Chryzostoma, św. Bazylego Wielkiego, autora pism apologetycznych, pastoralnych, ascetycznych i egzegetycznych św. Atanazego ${ }^{26}$, poety i wybitnego mówcy - św. Grzegorza z Nazjanzu ${ }^{27}$. Znajdowały się też dzieła Dionizego Ecclesiastica hierarchia oraz Coelesti hierarchia. Pierwsze odnosi się do sakramentów, duchowieństwa i świeckich, drugie wyjaśnia pośrednictwo dziewięciu chórów anielskich między Bogiem, a człowiekiem ${ }^{28}$. Razem w tym dziale znajdowało się 36 pozycji w 66 woluminach.

Kolejny dział zawierał teksty z zakresu teologii spekulatywnej. Najbardziej reprezentatywną postacią jest św. Tomasz z Akwinu i jego monumentalne dzieło Summa Theologica, którego poszczególne części występują w kilkunastu egzemplarzach. Z komentatorów Akwinaty inwentarz wymienia tylko jednego, również dominikanina, Tomasza Kajetana (Tomasso de Vio), który w XVI wieku na nowo wskrzesił tomizm ${ }^{29}$. Na uwagę zasługuje również często publikowana w XV i XVI stuleciu Summa theologiae franciszkanina, współtwórcy metody scholastycznej Aleksandra z Hales ${ }^{30}$.

Nie można nie zauważyć Sententiarum libri quatuor Piotra Lombarda, które występuje w czterech egzemplarzach. To niezwykle popularne dzieło, zawierające wiele cytatów z pism ojców Kościoła, zwłaszcza św. Augustyna i Jana Damasceńskiego, było podstawowym podręcznikiem teologii katolickiej w średniowieczu, wyparte później zostało przez Summę teologiczna św. Tomasza z Akwinu ${ }^{31}$. Księga sentencji Lombarda komentowana była przez niemal wszystkich znanych teologów. W wileńskim księgozbiorze były komentarze św. Bonawentury, św. To-

${ }^{22}$ L. Małunowiczówna, Ambroży, EK, t. 1, red. F. Gryglewicz, R. Łukaszyk, Z. Sułowski, Lublin 1973, kol. 411-415.

${ }^{23}$ E. Stanula, Hieronim, EK, t. 6, red. J. Walkusz, Lublin 1993, kol. 851-853.

${ }^{24}$ W. Myszor, Cyprian, EK, t. 3, red. R. Łukaszczyk, L. Bieńkowski, F. Gryglewicz, Lublin 1979, kol. 690-693.

${ }^{25}$ M. Wysocki, Tertulian, EK, t. 19, red. S. Wilk, Lublin 2013, kol. 731-735.

${ }^{26}$ E. Florkowski, Atanazy Wielki, EK, t. 1, red. F. Gryglewicz, R. Łukaszyk, Z. Sułowski, Lublin 1973, kol. 1026-1029.

${ }^{27}$ F. Drączkowski, Grzegorz z Nazjanzu, EK, t. 6, red. J. Walkusz, Lublin 1993, kol. 313-316.

${ }^{28}$ Enc. Kościoła, t. 1, s. 519.

${ }^{29}$ P. Moskal, Kajetan, EK, t. 8, red. B. Migut, Lublin 2000, kol. 338-339; zob. też, S. Świeżawski, Studia z myśli późnego średniowiecza, Warszawa 1998, Świeżawski, Święty Tomasz na nowo odczytany, Poznań 2002; J-P. Torell, Tomasz z Akwinu - człowiek i dzieło, Kęty-Warszawa 2008.

${ }^{30}$ J. Wawro, Aleksander z Hales, EK, t. 1, red. F. Gryglewicz, R. Łukaszyk, Z. Sułowski, Lublin 1973, kol. 335-340.

${ }^{31}$ Enc. Kościoła, t. 2, s. 501; E. Wójcik, Piotr Lombard, EK, t. 15, red. S. Wilk, Lublin 2011, kol. 678-681. 
masza z Akwinu, jego nauczyciela św. Alberta Wielkiego ${ }^{32}$, Piotra de Palude oraz twórczo rozwijającego doktrynę Akwinaty Jeana Capreolusa ${ }^{33}$. Ogółem w tym dziale widnieją 33 tytuły w 44 woluminach.

W księgozbiorze spotykamy też prace z zakresu teologii moralnej. Do najbardziej cenionych dzieł należała Summa aurea de vitiis et virtutibus Wilhelma Peraldusa, która była opracowaniem wysoko cenionym przez kaznodziejów oraz jego autorstwa Exempla virtutum et vitiorum ${ }^{34}$. Równie ważne były, do pewnego stopnia ze sobą powiązane, prace innych przedstawicieli tego zgromadzenia - Summa confessorum, prawdopodobnie autorstwa Jana z Fryburga ${ }^{35}$, Summa de casibus conscienciae kaznodziei i pisarza teologicznego Bartłomieja z San Concordio oparta na pracy wyżej wymienionego, ale opracowana w układzie alfabetycznym i szeroko rozpowszechniona w XIV i XV oraz w kolejnych stuleciach, w Polsce znana pod tytułem Summa pisana lub też Pisanella ${ }^{36}$. W XV wieku franciszkanin Anioł Carletti z Chivasso włączył ją do swojego dzieła Summa causum conscientiae, znanego też pod nazwą Summa Angelica ${ }^{37}$. Ten podręcznik teologii moralnej i prawa kanonicznego wileńscy dominikanie posiadali w dwóch egzemplarzach. W takiej samej liczbie woluminów widnieje również skrót innego podręcznika Summa Silvestrina pióra dominikanina Sylwestra z Priero ${ }^{38}$. Znanym i cenionym moralistą był też teolog i filozof Jan Gerson ${ }^{39}$. W księgozbiorze była trzytomowa zbiorowa edycja jego dzieł.

Ponieważ do początku XVII wieku teologia moralna obejmowała również teologię pastoralną, do działu tego należałoby zaliczyć dzieło znakomitego francuskiego kanonisty i liturgisty z XIII wieku Guillaume Duranda ${ }^{40}$. Jego Rationale divinorum officiorum dominikańska libraria posiadała w trzech egzemplarzach. W tej grupie piśmiennictwa teologicznego występują również Opuscula Jakuba Fabra, które zawierały De sacrosanctae missae sacrificio ac de sacerdotio nova legis ${ }^{41}$.

W ścisłym związku z teologią pastoralną pozostawały wydawnictwa katechetyczne, reprezentowane przez dwa katechizmy: Fryderyka Nausea Catholi-

${ }^{32}$ M. Kurdziałek, Albert Wielki, EK, t. 1, red. F. Gryglewicz, R. Łukaszyk, Z. Sułowski, Lublin 1973, kol. 301-302.

${ }^{33}$ R. Waszkinel, Caprelous Jean, EK, t. 2, red. F. Gryglewicz, R. Łukaszyk, Z. Sułowski, Lublin 1976, kol. 1322-1323.

${ }^{34}$ Lexikon für Theologiae, t. 8, kol. 78-79.

${ }^{35}$ Lexikon für Theologiae, t. 5, kol. 1033-1034; M. Daniluk, Jan z Fryburga, EK, t. 7, red. S. Wielgus, Lublin 1997, kol. 891

${ }^{36}$ S. Witek, Barttomiej z San Concordio, EK, t. 2, red. F. Gryglewicz, R. Łukaszyk, Z. Sułowski, Lublin 1976, kol. 81.

${ }^{37}$ H. Fros, Aniot Carletti z Chivasso, EK, t. 1, red. F. Gryglewicz, R. Łukaszyk, Z. Sułowski, Lublin 1973, kol. 613.

${ }^{38}$ Enc. Kościoła, t. 2, s. 567.

${ }^{39}$ S. Wielgus, Gerson Jan, EK, t. 5, red. L. Bieńkowski, Lublin 1989, kol. 1118-1119.

${ }^{40}$ E. Przekop, Durand Guillaume Starszy, EK, t. 4, red. R. Łukaszyk, L. Bieńkowski, F. Gryglewicz, Lublin 1984, kol. 368-369.

${ }^{41}$ Biographisch-bibliographisches Kirchenlexikon, Bd. 1, Hamm 1990, kol. 1589. 
cus Catechismus oraz Catechismus Polonicus ${ }^{42}$. Piśmiennictwo z tego zakresu w książnicy dominikańskiej reprezentowane jest przez 17 pozycji w 21 woluminach. Nie jest to dział szczególnie rozbudowany, zawiera jednak ważne, niekiedy fundamentalne dzieła dotyczące tej problematyki.

Na kolejny dział piśmiennictwa w wileńskim księgozbiorze składały się książki o tematyce ascetyczno-mistycznej. Zauważamy w nim Medytacje św. Augustyna oraz dzieła ascetyczne św. Bonawentury - franciszkańskiego teologa i filozo$\mathrm{fa}^{43}$. Dominikanie z konwentu Św. Ducha posiadali także Sermones cantica canticorum pióra św. Bernarda z Clairvaux, które zawierało 86 mów komentujących w sensie alegoryczno-mistycznym dwa pierwsze rozdziały Pieśni nad Pieśnia$m i^{44}$. Omawiając wszystkie stadia życia duchowego stanowiło główne źródło poznania jego mistyki oraz życia zakonnego w Clairvaux. Nie zabrakło Opusculum piętnastowiecznego niderlandzkiego teologa i mistyka Dionizego Kartuza ${ }^{45}$. Jego poglądy ascetyczno-mistyczne szeroko były rozpowszechnione w XVI stuleciu w Europie środkowej, w tym również w Rzeczypospolitej. Nie można zapomnieć o Revelationes czternastowiecznej szwedzkiej mistyczki św. Brygidy, zawierających teksty jej objawień, spisane przez jej otoczenie ${ }^{46}$. Był to dział nader skromny, liczył bowiem siedem pozycji bibliograficznych w siedmiu woluminach.

Znacznie więcej książek obejmuje kolejny dział, zawierający zarówno opracowania doktryny katolickiej i jej dogmatów, jak i bogatą literaturę polemiczną okresu reformacji, która nastawiona była na obronę podstawowych zasad wiary, kwestionowanych przez innowierców oraz wyjaśnienie ich błędów. Spośród pisarzy starożytnych inwentarz odnotowuje tylko dwa egzemplarze dzieła doktora Kościoła Epifaniusza, występującego pod tytułem Contra octoginta haeres opus, w którym autor skrupulatnie wylicza kolejno następujące po sobie herezje. Stanowi ono swoistą kompilację różnych ruchów uznanych za herezję od początków dziejów Kościoła do V wieku ${ }^{47}$. Była również praca św. Tomasza z Akwinu Summa contra Gentiles. Pozostałe pozycje dotyczą doby reformacji, a ich autorzy podejmują dyskusję z poglądami Marcina Lutra. $Z$ dorobku szesnastowiecznych, reprezentujących ten krąg autorów znajdują się trzy egzemplarze dzieła znanego niemieckiego polemisty Jana Hoffmeistera Loci communes rerum theologicarum, a także De sacrificio missae contra Lutheranos wielkiego szermierza kontrrefor-

${ }^{42}$ O katechizmach zob. M. Rusecki, Katechizm, EK, t. 8, red. B. Migut, Lublin 2000, kol. 10381047.

${ }^{43}$ E. Zieliński, Bonawentura, EK, t. 2, red. F. Gryglewicz, R. Łukaszyk, Z. Sułowski, Lublin 1976, kol. 780-785.

${ }^{44}$ S. Kędziora, J. Misiurek, Bernard z Clairvaux, EK, t. 2, red. F. Gryglewicz, R. Łukaszyk, Z. Sułowski, Lublin 1976, kol. 301-302.

${ }^{45}$ A. Bazielich, Dionizy Kartuz, EK, t. 3, red. R. Łukaszyk, L. Bieńkowski, F. Gryglewicz, Lublin 1979, kol. 1339-1340.

${ }^{46}$ J. Kłoczowski, Brygida Szwedzka, EK, t. 2, red. F. Gryglewicz, R. Łukaszyk, Z. Sułowski, Lublin 1976, kol. 1115-1116.

${ }^{47}$ F. Drączkowski, Epifaniusz, EK, t. 4, red. R. Łukaszyk, L. Bieńkowski, F. Gryglewicz, Lublin 1984, kol. 1021-1023. 
macji Jana Ecka oraz dwa inne jego teksty ${ }^{48}$. Jest też In Martinum Lutrum oratio Alojzego Marliani.

Poza tym inwentarz wymienia nazwiska wielu innych teologów katolickich, którzy przy pomocy swoich publikacji walczyli z tezami twórców i propagatorów reformacji protestanckiej. Spis wykazuje Adversus omnes haeres hiszpańskiego franciszkanina Alfonsa de Castro, zawierające w porządku alfabetycznym wszystkie współczesne herezje i zwalczające je tezy ${ }^{49}$. Było też Speculum haereticorum dominikanina ze Sieny Ambrożego Politi oraz Catalogus haereticorum omnium Bernarda z Luksemburga, z którego korzystano przy redagowaniu indeksu ksiąg zakazanych ${ }^{50}$. Spis odnotowuje też kilka dzieł polskich polemistów. Uwagę zwraca pozycja polskojęzyczna - O jedności Kościoła Bożego pod jednym pasterzem Piotra Skargi ${ }^{51}$. Znajdowały się również dwie prace Stanisława Hozjusza: Confutatio prolegomena Brentii oraz Confessio fidei catholicae christianae - wielokrotnie publikowane w różnych oficynach wielu krajów ${ }^{52}$. Są też dwa dzieła doktora obojga praw, teologa polemisty Jakuba Górskiego ${ }^{53}$ oraz autora pism religijnych i politycznych Stanisława Orzechowskiego. Łącznie dział ten liczy 34 pozycje w 39 woluminach.

W księgozbiorze dominikańskim nie mogło zabraknąć literatury kaznodziejskiej, wszak głównym celem tego zgromadzenia było głoszenie słowa Bożego. Można sądzić, że po tego rodzaju książki miejscowi zakonnicy sięgali najczęściej. Stanowiąca największą część księgozbioru grupa tego rodzaju piśmiennictwa obejmowała wszystkie odmainy wymowy kościelnej, od nielicznych prac z teorii wymowy po dużą liczbę praktycznych zbiorów kazań. Wśród nich znajdowały się zarówno proste homilie, jak i kunsztownie zbudowane kazania, które retoryka kościelna nazywa sermones. Równie rozległa była ich tematyka - od kazań polemicznych po żałobne homilie. W okresie reformacji, gdy potrzebą chwili była bezpośrednia polemika, oparta o kanony retoryki Arystotelesa i Cycerona, teoria wymowy musiała ustąpić na dalszy plan. Podstawą kazań, których celem było budzenie i utrwalanie wiary stał się tekst biblijny ${ }^{54}$. W posiadaniu biblioteki były tylko dwie części wielotomowego wydania Ecclesiasticae rhetoricae dominikanina Ludwika z Granady oraz traktat na temat kompozycji kazań De emendata

${ }^{48}$ H. Wojtyska, Eck Johann, EK, t. 4, red. R. Łukaszyk, L. Bieńkowski, F. Gryglewicz, Lublin 1984, kol. 648-649.

${ }^{49}$ E. Sokołowski, Alfons de Castro, EK, t. 1, red. F. Gryglewicz, R. Łukaszyk, Z. Sułowski, Lublin 1973, kol. 258.

${ }^{50}$ H. Wojtyska, Bernard z Luksemburga, EK, t. 2, red. F. Gryglewicz, R. Łukaszyk, Z. Sułowski, Lublin 1976, kol. 308.

${ }^{51}$ J. Tazbir, Skarga Piotr, w: Polski stownik biograficzny (dalej: PSB), t. 37, red. H. Markiewicz, Warszawa 1997, s. 35-43; Piotr Skarga, w: Encyklopedia wiedzy o jezuitach na ziemiach Polski i Litwy 1564-1995, oprac. L. Grzebień SJ, Kraków 2004, s. 619-620.

${ }^{52}$ J. Misiurek, Hozjusz Stanisław, EK, t. 6, red. J. Walkusz, Lublin 1993, kol. 1258; Kardynat Stanisław Hozjusz (1504-1579): osoba, myśl, dzieło, czasy, znaczenie, red. S. Archemczyk, J. Guzowski, J. Jezierski, Olsztyn 2005.

${ }^{53}$ H. Barycz, Jakub Górski, PSB, t. 8, red. K. Lepszy, Wrocław 1959/1960, s. 438-440.

${ }^{54}$ M. Brzozowski, Teoria kaznodziejstwa (wiek XVI-XVIII), w: Dzieje teologii katolickiej w Polsce, red. M. Rechowicz, t. 2, cz. 1: Od Odrodzenia do Oświecenia, Lublin 1975, s. 363-365. 
structura latini sermones w sześciu księgach autorstwa humanisty Tomasza Linacre ${ }^{55}$. Natomiast praktyczna literatura homiletyczna obejmuje niemal wszystko, co ukazywało się wówczas na rynku wydawniczo - księgarskim. Z dawniejszych kaznodziejów znalazły się w księgozbiorze dominikańskim zbiory kazań ojców i doktorów Kościoła: św. Jana Chryzostoma, św. Cypriana, św. Bonawentury, Bazylego Wielkiego oraz filozofa, teologa i nauczyciela Tomasza z Akwinu - Alberta Wielkiego. Widnieją też homilie Bedy Czcigodnego, które stanowią w kościelnym piśmiennictwie iroszkockim i anglosaskim jedyny zachowany zbiór kazañ ${ }^{56}$. $\mathrm{Z}$ pism teologów scholastycznych inwentarz odnotowuje aż pięć egzemplarzy Sermones thesauri novi de tempore et de sanctis profesora teologii na paryskiej Sorbonie dominikanina Piotra de Palude ${ }^{57}$ oraz Sermones Hugo z Sancto Caro. Z dzieł piętnastowiecznych kaznodziejów dominikańskich są dwa zbiory kazań znanego hiszpańskiego teologa Jana Turrecrematy ${ }^{58}$, dwa egzemplarze Sermones quadragesimales Leonarda z Utino ${ }^{59}$ oraz Sermones de tempore et de sanctis per totum annum i Sermones de tempore et de sanctis Piotra z Hieremia ${ }^{60}$. Znajdujemy ponadto dwie prace kaznodziejskie słynnego dominikanina, kaznodziei i pisarza hagiograficznego Jakuba de Voragine ${ }^{61}$ oraz napisane w przystępnej formie i wielokrotnie wydawane Sermones znanego dominikańskiego kaznodziei ludowego Gabriela Baraletta ${ }^{62}$. Inwentarz odnotowuje także zbiory kazań franciszkańskich kaznodziejów - Bernarda de Tour ${ }^{63}$ i Roberta Carraciolo ${ }^{64}$ oraz szwajcarskiego teologa Jana Geigera, którego kazania przełożył na język łaciński i opublikował Sebastian Brandt ${ }^{65}$.

Największą grupę prac homiletycznych stanowią aktualne w owym czasie kazania autorów żyjących i tworzących w XVI stuleciu, co niewątpliwie świadczy o trafnym doborze książek przydatnych do wypełniania zadań, przed jakimi stali wileńscy dominikanie w dobie reformacji. Są w niej cztery homilie Jana Ecka ${ }^{66}$ oraz Homiliarum ewangelicae veritatis centuriae Fryderyka Nausea ${ }^{67}$. Z kazań opartych na tekście biblijnym były homilie Jana Hoffmeistera, w dwóch egzemplarzach dzieło franciszkanina Henryka Helma z Halberstadt ${ }^{68}$ oraz w trzech egzemplarzach tego rodzaju praca karmelity Tomasza Beauxamis ${ }^{69}$. Nie zabrakło

${ }^{55}$ Enc. Kościoła, t. 2, s. 58.

${ }^{56}$ M. Starowieyski, Beda Czcigodny, EK, t. 2, red. F. Gryglewicz, R. Łukaszyk, Z. Sułowski, Lublin 1976, kol. 169-171.

${ }^{57}$ Podręczna encyklopedia kościelna, t. 29-30, red. S. Gall, Warszawa 1913, s. 332.

${ }^{58}$ Enc. Kościoła, t. 2, s. 1012.

${ }^{59}$ Lexikon für Theologie, t. 6, Freiburg 1961, kol. 967.

${ }^{60}$ Lexikon für Theologie, t. 8, Freiburg 1963, kol. 363.

${ }^{61}$ J. Zbiciak, Jakub de Voragine, EK, t. 7, red. S. Wielgus, Lublin 1997, kol. 713-714.

${ }^{62}$ Dictionaire d'histoire et de geographie ecclesiastiques, t. 6, Paris 1932, kol. 841-842.

${ }^{63}$ Lexikon für Theologie, t. 2, Freiburg 1958, kol. 272.

${ }^{64}$ Lexikon für Theologie, t. 2, Freiburg 1958, kol. 933.

${ }^{65}$ F. Gołębiowski, Geiger Johannes, EK, t. 5, red. L. Bieńkowski, Lublin 1989, kol. 930.

${ }^{66}$ Wojtyska, Eck Johann, kol. 648-649.

${ }^{67}$ Lexikon für Theologie, t. 7, Freiburg 1962, kol. 847.

${ }^{68}$ Dictionaire d'histoire, t. 23, Paris 1990, kol. 934-935.

${ }^{69}$ Lexikon für Theologie, t. 2, Freiburg 1958, kol. 88. 
wzorów kazań wyjaśniających niedzielną ewangelię autorstwa wybitnego franciszkańskiego kaznodziei Antonia z Bitonto oraz kartuza Jana Lansperga ${ }^{70}$. Były również postylle niemieckiego humanisty Georga Witzela ${ }^{71}$ i Fryderyka Nausea, a także dwutomowa Summa praedicantium kapucyna Filipa Dietza ${ }^{72}$.

Najliczniejszą grupę stanowią zbiory kazań układanych w roczne cykle na niedziele i święta. Do grona ich autorów należeli: flamandzki humanista i teolog Josse Clichtove ${ }^{73}$, Antoni z Vercelli, Michał z Węgier, Michael Lochmaier, znany jako kaznodzieja pokutny Wincenty Ferrier ${ }^{74}$ oraz autor około stu kazań norbertanin Adam Szkot ${ }^{75}$. Dominikanie gromadzili też kazania maryjne, które reprezentowane są przez obszerne, obrazujące w cyklu 63 kazań życie Najświętszej Marii Panny dzieło Mariale Bernardyna z Busti oraz tegoż autora zawierające szkice wygłoszonych kazań Rosarium sermonum praedicabilium ${ }^{76}$. Tego rodzaju dzieła pisał też Pelbart z Temeswar ${ }^{77}$. Cieszyły się one uznaniem wśród dominikanów, bowiem inwentarz odnotowuje dziewięć egzemplarzy jego pism.

Jeszcze inny typ kazań reprezentują kazania pogrzebowe. Zauważyć można wśród nich Sermones funebres dominikanina Jana Gorusa oraz okolicznościową mowę wygłoszoną przez biskupa Samuela Maciejowskiego na pogrzebie Zygmunta I Starego w 1548 r. Ogólnie w dziale tym było 89 zbiorów kazań i pojedynczych tego rodzaju tekstów w 98 woluminach. Była to zatem blisko piąta część księgozbioru, co zdaje się świadczyć o tym, że dominikanie wileńscy sumiennie przygotowywali się do obowiązków duszpasterskich, które na nich spoczywały i wynikały z ich podstawowej misji.

$\mathrm{Z}$ piśmiennictwem homiletycznym łączy się dział, w którym znalazły się teksty hagiograficzne. W księgozbiorze wileńskich dominikanów znajdowały się trzy egzemplarze niezwykle popularnego dzieła Jakuba de Voragine Legenda sanctorum Ordinis Praedicatorum, powszechnie znanego pod nazwą Legenda aurea. Znana była również pod tytułem Lombardia historia, ponieważ zawierała materiały do dziejów tej włoskiej prowincji dominikańskiej i inwentarz rejestruje ją pod tą właśnie nazwą ${ }^{78}$. Biblioteka posiadała także niezwykle popularne, wielokrotnie publikowane Żywoty świętych Piotra Skargi ${ }^{79}$ oraz Vitae sanctorum Po-

${ }^{70}$ Enciclopedia ecclesiastica, t. 5. Milano 1952, s. 469.

${ }^{71}$ Lexikon für Theologie, t. 10, Freiburg 1965, kol. 1205.

${ }^{72}$ Lexikon für Theologie, t. 3, Freiburg 1959, kol. 322.

${ }^{73}$ W. Danielski, Clichtove Josse, EK, t. 3, red. R. Łukaszyk, L. Bieńkowski, F. Gryglewicz, Lublin 1979, kol. 511-512.

${ }^{74}$ Biographish-bibliographisches Kirchenlexikon, t. 2, Hamm 1990, kol. 20.

${ }^{75}$ S. Smoleński, Adam Szkot, EK, t. 1, red. F. Gryglewicz, R. Łukaszyk, Z. Sułowski, Lublin 1973, kol. 73 .

${ }^{76}$ J. Lewicki, Bernardyn z Busti, EK, t. 2, red. F. Gryglewicz, R. Łukaszyk, Z. Sułowski, Lublin 1976, kol. 312.

${ }^{77}$ Encyklopedia kościelna, t. 19, red. M. Nowodworski, Warszawa 1893, s. 25.

${ }^{78}$ Zob., M. Plezia, Wstęp, w: Jakub de Voragine. Złota legenda. Wybór, Warszawa 1955, s. I-LXXXVII.

${ }^{79}$ Tazbir, Skarga Piotr, s. 35-43. 
lonorum znanego hagiografa Marcina Baroniusza ${ }^{80}$. W spisie pojawiają się jeszcze dwa ogólne dzieła hagiograficzne Vita Patrum Ordinis Praedicatorum oraz Catalogus scriptorum ecclesiasticorum sive illustrium virorum prawdopodobnie autorstwa Jana Trithema $\mathrm{z}$ Heidelbergu ${ }^{81}$. W sumie do tego działu można przyporządkować 12 pozycji w takiej samej liczbie woluminów.

W każdej bibliotece klasztornej znaczące miejsce zajmowało piśmiennictwo poświęcone historii kościelnej i świeckiej. Tak też było w przypadku librarii wileńskiej. Uwagę zwraca aż cztery egzemplarze monumentalnego dzieła starożytnego historyka, apologety i biblisty Euzebiusza z Cezarei Historia Ecclesiastica, które stanowi pierwszą próbę przedstawienia dziejów Kościoła od jego założenia do czasów Konstantyna Wielkiego. Zredagowane w porządku chronologicznym ma do chwili obecnej wielką wartość z uwagi na zamieszczone w nim cytaty dzieł zaginionych ${ }^{82}$. Inwentarz odnotowuje również Ecclesiasticae historiae gentis Anglorum ojca historiografii angielskiej - Bedy Czcigodnego. Dzieło to posiada dodatkową wartość z uwagi na autobiografię autora i wykaz jego dzieł ${ }^{83}$. Nowożytną historiografię kościelną reprezentuje praca augustianina Jakuba Foresti $\mathrm{z}$ Bergamo Supplementum supplementi chronicarum ab ipso mundi, w którym autor wiele miejsca poświęcił współczesnym postaciom Kościoła ${ }^{84}$. Oprócz obszernych opracowań historii kościelnej było też dzieło dotyczące historiografii zakonnej franciszkanina Andrei Fabiani ${ }^{85}$.

Świecką historiografię reprezentowały przede wszystkim prace autorów starożytnych. W księgozbiorze znajdowało się dzieło Valeriusa Maximusa oraz dwa egzemplarze Naturalis historiae Pliniusza Starszego - dzieła o charakterze encyklopedycznym, zawierającym informacje z zakresu wszystkich ówczesnych dziedzin życia ${ }^{86}$. Mimo, iż jego zakres wychodził poza granice historiografii, to w bibliotekach klasztornych umieszczane było właśnie w tym dziale. Zgodnie $\mathrm{z}$ ówczesnym pojęciem zakresu historii $\mathrm{w}$ jej obszar wchodziły również opisy krajów i obyczajów różnych ludów oraz podróży. Tego rodzaju piśmiennictwo również wypełniało półki klasztornej biblioteki wileńskiej, między innymi Epitome trium terrae partium Asiae, Africae et Europeae Joachima Vadiana.

Polską historiografię reprezentował thumaczony na obce języki Traktat o dwóch Sarmacjach Macieja Miechowity oraz inne jego dzieło Chronica Polonorum $^{87}$. Kolejnym teksten jest Diarii et larum quae memoratu digna in spendi-

${ }^{80}$ M. Daniluk, Baroniusz Marcin, EK, t. 2, red. F. Gryglewicz, R. Łukaszyk, Z. Sułowski, Lublin 1976, kol. 62 .

${ }^{81}$ Lexikon für Theologie, t. 10, Freiburg 1965, kol. 366.

${ }^{82}$ F. Drączkowski, Euzebiusz z Cezarei, EK, t. 4, red. R. Łukaszyk, L. Bieńkowski, F. Gryglewicz, Lublin 1984, kol. 1351-1352.

${ }^{83}$ Starowieyski, Beda Czcigodny, kol. 169-170.

${ }^{84}$ Enc. Ecclesiastica, vol. 3, Milano 1949, s. 392.

${ }^{85}$ A. Jastrzębski, Fabiani Andrea, EK, t. 5, red. L. Bieńkowski, Lublin 1989, kol. 5.

${ }^{86} \mathrm{O}$ dziele, autorze i jego twórczości, zob. L. Hajdukiewicz, Wstęp, w: Pliniusz, Historia naturalna (wybór), Wrocław 1961, s. I-LXXVIII.

${ }^{87} \mathrm{H}$. Barycz, Życie i twórczość Macieja z Miechowa. Pochodzenie, studia, podróże, w: Maciej z Miechowa 1457-1523. Historyk, geograf, lekarz i organizator nauki, Wrocław 1960, s. 15-74. 
dissimis ...Sigismundi...et Bonae... historyka, ekonomisty i sekretarza Zygmunta Starego Jodoka Ludwika Decjusza ${ }^{88}$.

Biblioteka była dobrze zaopatrzona w źródła prawa kanonicznego, które stanowiły przede wszystkim Decretales libri $V$ Grzegorza IX, Liber sextus decretalium Bonifacego VIII oraz Constitutiones Klemensa V. Pierwsze z dzieł, występujące w dwóch egzemplarzach, powstało z polecenia papieża Grzegorza IX. Jego autor - dominikanin Rajmund z Penafort - zebrał w nim głównie dekretały papieskie i soborowe oraz konstytucje Grzegorza IX. Określa się je jako ius novum w przeciwieństwie do ius vetus zawierającym między innymi Dekret Gracjana. Obok dawnego prawa stało się ono podstawą nauczania oraz orzecznictwa sądów kościelnych. Zarejestrowana w pięciu egzemplarzach Liber sextus decretalium łączy się z działalnością ustawodawczą papieża Bonifacego VIII. Opracowana przez trzyosobową komisję i stanowiąca uzupełnienie pięciu ksiąg Decretales ogłoszona została w 1298 r. i miała charakter kodeksu prawa kanonicznego. Do tego zbioru papież Klemens V w 1314 r. dołączył tak zwane Clementinae. W spisie widnieją dwa zbiorowe wydania Liber sextus decretalium i Clementinae. Te trzy kompilacje prawa kanonicznego wchodzą w skład Corpus iuris canonici, czyli grupy sześciu ksiąg zawierających normy średniowiecznego prawa kanonicznego ${ }^{89}$. Wileńska książnica posiadała zatem niemal kompletny zbiór tego prawa, a poszczególne jego części posiadały ponadto komentarze wielu wybitnych prawników. Ceniony był wyciąg z Dekretu Gracjana, zwany Margarita Decreti - podręczne kompendium wiedzy kanoniczej średniowiecznej, wielokrotnie kopiowane i drukowane, sporządzone przez dominikanina Marcina Polaka ${ }^{90}$. Z opracowań prawa kanonicznego biblioteka posiadała jeszcze zbiór Casus longi super quinque libros decretalium Bernarda z Botony, którego uczniem był Wilhelm Durand - autor widniejącego także w spisie Repertorium iuris ${ }^{91}$. Ustawodawstwo zakonne reprezentowały reguły oraz konstytucje - Regula beati Augustini i Constitutiones Fratrum Ordinis Praedicatorum, a także statuty gnieźnieńskich synodów prowincjonalnych. W posiadaniu zakonników były również kanony i dekrety Soboru Trydenckiego.

Osiedlający się i żyjący w mieście zakonnicy starali się mieć wiedzę w zakresie prawa miejskiego. Włączyli zatem do swego księgozbioru Speculum Saxonum. Nie zabrakło też Kodeksu Justyniana. Ogółem w dziale tym znajdowało się 29 dzieł w takiej samej liczbie woluminów.

${ }^{88}$ W. Pociecha, Decjusz Jost Ludwik, PSB, t. 5, red. W. Konopczyński, Kraków 1939/1946, s. $42-45$.

${ }^{89}$ A. Vetulani, Corpus iuris canonici, EK, t. 3, red. R. Łukaszyk, L. Bieńkowski, F. Gryglewicz, Lublin 1979, kol. 598-599; Enc. Kościoła, t. 1, s. 822, 1157.

${ }^{90}$ K. Grodziska-Ożóg, Marcin Polak i jego twórczość, „Nasza Przeszłość”, 58 (1983) s. 169201.

${ }^{91}$ H. Rybczyński, Bernard z Botony, EK, t. 2, red. F. Gryglewicz, R. Łukaszyk, Z. Sułowski, Lublin 1976, kol. 300. 
W dziale zawierającym prace filozoficzne widnieją dokonania starożytnych filozofów, reprezentowane przez pisma Platona i trzy dzieła Arystotelesa ${ }^{92}$ : Duodecim libri Methaphisicae, Liber de generatione et interimu oraz Problemata. Oprócz oryginalnych tekstów Stagiryty inwentarz rejestruje komentarze do jego dzieł, między innymi Isagogę neoplatonika z III wieku Porfiriusza oraz Paraphrasis in Aristotelis posteriori et phisica Themistusa Peripateticusa. Są też komentarze do Metafizyki, Fizyki, Etyki franciszkańskiego filozofa i teologa Jana Dunsa Szkota, Jana Versora, św. Alberta Wielkiego, św. Tomasza z Akwinu, Pawła Barbo i Angelo Poliziano. W księgozbiorze znajdował się również Enchirydion rzymskiego filozofa Epikteta w opracowaniu jego ucznia i komentatora Flawiusza Arianusa ${ }^{93}$, a także Opera filozofa i apologety chrześcijańskiego z Kartaginy Tertuliana oraz dwa egzemplarze dzieł twórcy szkoły w Aleksandrii Orygenesa. $\mathrm{Z}$ pism filozofów średniowiecznych w dominikańskiej bibliotece znajdowało się De proprietatibus rerum Bartłomieja Anglika ${ }^{94}$ oraz podręcznik dialektyki Summulae logicales Piotra Hiszpana, późniejszego papieża Jana XXI ${ }^{95}$. Ogółem do działu tego należy zaliczyć 36 dzieł w 37 woluminach.

W bibliotece dominikańskiej nie mogło zabraknąć gramatyk i dzieł leksykograficznych, służących do nauki języka łacińskiego. Z pism gramatyków starożytnych widnieją dwa teksty Aurelego Macrobiusa - Somnium Scipionis i Saturnaliom libri VII. Były też dwie niezwykle popularne w średniowieczu prace Aleksandra z Villa Dei Doctrinale totus gramatices oraz Catholicon czyli Summa gramaticales dominikanina Jana Balbusa. Z dzieł leksykograficznych na uwagę zasługuje Dictionarium latinae lingua Ambrożego Calepino ${ }^{96}$. Słownik, w którym autor wyjaśniał znaczenie słów łacińskich posługując się zwrotami, przysłowiami i sentencjami zaczerpniętymi z pism autorów klasycznych i chrześcijańskich w XVI stuleciu był wielokrotnie wznawiany, a jego kontynuatorzy wzbogacali go zarówno w warstwie łacińskiej, jak w różnojęzycznych znaczeń doprowadzając do powstania Dictionarium undecim linguarum, w tym także języka polskiego. W księgozbiorze znalazł również miejsce Lexicon latino - polonicum polskiego leksykografa z XVI wieku Jana Mączyńskiego, który był pierwszym wielkim słownikiem polsko-łacińskim, uzupełnionym wiadomościami z dziedziny kosmografii, historii, gramatyki i mitologii ${ }^{97}$. Do nauki języka greckiego służył Lexicon graecum.

${ }^{92}$ M. Krąpiec, Arystoteles, EK t. 1, red. F. Gryglewicz, R. Łukaszyk, Z. Sułowski, Lublin 1973, kol. 962-967.

${ }^{93}$ F. Wawrzyniak, Epiktet z Hierapolis, EK, t. 4, red. R. Łukaszyk, L. Bieńkowski, F. Gryglewicz, Lublin 1984, kol. 1031-1032.

${ }^{94}$ M. Kurdziałek, Bartłomiej Anglik, EK, t. 2, red. F. Gryglewicz, R. Łukaszyk, Z. Sułowski, Lublin 1976, kol. 75.

${ }^{95}$ S.A. Bogacewicz, A. Rogalski, Jan XXI, EK, t. 7, red. S. Wielgus, Lublin 1997, kol. 831-833.

${ }^{9}$ J. Duchniewski, Calepio, Calepino Ambrogio, EK, t. 2, red. F. Gryglewicz, R. Łukaszyk, Z. Sułowski, Lublin 1976, kol. 1278-1279.

${ }^{97}$ H. Barycz, Jan Maczyński, leksykograf polski XVI wieku, „Reformacja w Polsce” 3 (1924) s. 218-255; Z. Klemensiewicz, O Janie Mączyńskim w czterechsetlecie jego dzieła, „Język Polski”, 44 (1964) nr 2 s. 65-75. 
Wśród książek wykorzystywanych w nauczaniu nie mogło zabraknąć takich, które rozwijały umiejętność pięknego wysławiania się, co było niezwykle istotne w zakonie kaznodziejskim. Zestaw dających podstawę retoryce gramatyk i słowników uzupełniony był różnymi podręcznikami frazeologii klasycznej, zestawieniami figur retorycznych, formularzami listów i wzorami ćwiczeń stylistycznych, mającymi podnieść elokwencję kaznodziejską. Służyć temu miał występujący w dwóch egzemplarzach traktat ustalający kanon łaciny renesansowej De elegantiarum lingua libri sex Lorenzo Valli. Z podręczników retoryki należy wymienić Progymnasmata in rhetoricam greckiego sofisty i retora Aphtoniusa oraz dzieło niemieckiego humanisty Albrechta von Eyb ${ }^{98}$. W dziale tym znalazły się 24 pozycje bibliograficzne w 29 woluminach.

W księgozbiorach klasztornych zazwyczaj występowały teksty autorów klasycznych. Tak też było w wileńskiej librarii dominikańskiej, w której obecne były dzieła Marka Tulisza Cycerona ${ }^{99}$ i Horacego. Ich klasyczna, czysta łacina była znakomitym środkiem do uzyskania pożądanego wykształcenia językowo-retorycznego. Przeważała w tym dziale twórczość wybitnego mówcy i filozofa Cycerona, który przekazał Rzymianom poglądy greckich myślicieli i stworzył łacińską terminologię filozoficzną, a którego dzieła wywarły wpływ na poglądy wielu ojców Kościoła, m.in. św. Ambrożego, św. Hieronima czy św. Augustyna. W spisie widnieją jego Listy, w których przekazał potomnym zasady epistolografii antycznej oraz Paradoxa, a także Heptalogium Wergiliusza. Księgozbiór zawierał również Orationes graeca lingua Demostenesa, Bajki Ezopa, Komedie Terencjusza i Plauta. Na ten stosunkowo nieliczny dział składało się 10 tytułów w 10 woluminach.

Klasztor nie tylko dbał o posiadanie dzieł autorów klasycznych, ale także łacińskich pisarzy nowożytnych, których utwory często charakteryzowały się piękną formą językową. Ich liczba ogranicza się jednak do kilku pozycji, ale zasługują one na uwagę. Spis rejestruje bowiem Listy i Moriae encomium Erazma z Rotterdamu ${ }^{100}$, Opera włoskiego humanisty Pico Della Mirandola, opracowanie wszystkich pism Horacego autorstwa Krzysztofa Landino ${ }^{101}$ oraz napisana piękną łaciną De Roma triumphante libri decem Flavio Bindo. Dział ten liczył pięć pozycji w takiej samej liczbie egzemplarzy.

Biblioteki klasztorne, w tym również wileńska, posiadały w swych zasobach również piśmiennictwo z zakresu nauk matematycznych i przyrodniczych. Zagadnień przyrodniczych dotyczył Tractatus de virtutibus herbarium pióra najprawdopodobniej Alberta Wielkiego, który zajmował się też anatomią, botaniką, chemią, geologią, zoologią i kosmologią utrzymując za Arystotelesem, że życie

${ }^{98}$ K. Bartoszewski, Eyb Albrecht, EK, t. 4, red. R. Łukaszyk, L. Bieńkowski, F. Gryglewicz, Lublin 1984, kol. 1475.

${ }^{99}$ R. Andrzejewski, Cyceron, EK, t. 3, red. R. Łukaszyk, L. Bieńkowski, F. Gryglewicz, Lublin 1979, kol. 677-678; K. Kumaniecki, Cyceron i jego wspótcześni, Warszawa 1989.

${ }^{100}$ J. Swastek, Erazm z Rotterdamu, EK, t. 4, red. R. Łukaszyk, L. Bieńkowski, F. Gryglewicz, Lublin 1984, kol. 1062-1063.

${ }^{101}$ Enc. ecclesiastica, t. 5, Milano 1952, s. 455. 
istnieje $w$ trzech formach: roślinnej, zwierzęcej i ludzkiej ${ }^{102}$. Przeważały jednak w tym dziale traktaty z zakresu medycyny. Była wśród nich praca Avicenny o leczeniu chorób, dzieła Hipokratesa i Klaudiusza Galena oraz De medicina libri VIII rzymskiego encyklopedysty Aulusa Corneliusa Celsusa ${ }^{103}$. Było to najwybitniejsze rzymskie dzieło o lecznictwie ze względu na trafną kompilację całej ówczesnej wiedzy medycznej. Odkryte w XV wieku było chętnie thumaczone i wielokrotnie wydawane aż do XVIII stulecia. W spisie widnieją także dwa traktaty bizantyńskiego lekarza z IV wieku Aleksandra z Tralles ${ }^{104}$. Z nowszych prac medycznych biblioteka posiadała Speculum medicinae katalońskiego lekarza i medyka z XIII wieku Arnolda z Villanova ${ }^{105}$. Była także w dwu egzemplarzach Practica francuskiego doktora i Bernarda de Gordon, nazwana w inwentarzu Lilium medicinae. Ogółem do tego działu należy zaliczyć 22 pozycje w takiej samej liczbie woluminów.

Inwentarz wymienia też księgi liturgiczne: Ordo missae, Missale Cracoviense, Breviarium Romanum, Breviarium Ordinis Praedicatorum i Graduale Ordinis Praedicatorum, które zapewne przechowywane były, podobnie jak we wszystkich domach zakonnych, w zakrystii lub na chórze.

Początek bibliotece dały zapewne książki przywiezione do Wilna przez pierwszych dominikanów, założycieli klasztoru i były to najprawdopodobniej inkunabuły. Inwentarz wymienia 92 zidentyfikowanych najwcześniejszych wytworów sztuki typograficznej, ale ich liczba mogła być jeszcze wyższa. Największa ich część pochodziła z Wenecji, na drugim miejscu uplasował się Strasburg, a w dalszej kolejności Bazylea, Kolonia, Lyon, Hagenau i Paryż. W następnych dziesięcioleciach napływały książki wytłoczone w innych przodujących wówczas oficynach europejskich. Przekazywane były klasztornej librarii zapewne - podobnie jak w większości tego rodzaju bibliotek - przez zakonników, wywodzących się z różnych grup darczyńców, a niekiedy w wyniku zakupów.

$\mathrm{Z}$ analizy inwentarza wynika, że profil zbiorów wileńskiego domu zakonnego zasadniczo nie różnił się od księgozbiorów innych bibliotek dominikańskich. Nie ulega wątpliwości, że zasób biblioteczny gromadzony był według pewnej myśli przewodniej. Jego struktura dostosowana była przede wszystkim do wymagań szkolnictwa zakonnego. Pozostawiło to widoczny ślad w układzie działowym, który oddaje program nauczania na poziomie trivium i quadrivium. Osobne działy posiadało piśmiennictwo z zakresu filozofii i teologii, które stanowiły najwyższe stopnie w strukturze studiów dominikańskich. Innym ważnym zadaniem biblioteki była pomoc w podstawowej misji zakonu, a więc w pracy kaznodziejskiej i duszpasterskiej. W dobie reformacji protestanckiej działalność ta pozostawała w ścisłym związku z aktualnym stanem rozłamu w Kościele łacińskim. Stąd też w księgozbiorze licznie reprezentowane były dzieła polemistów. Zewnętrzną formę kazań mogli zakonnicy doskonalić na wielu gotowych ich wzorach lub też

${ }^{102}$ Kurdziałek, Albert Wielki, kol. 305.

${ }^{103}$ Stownik kultury antycznej, red. R. Kulesza, Warszawa 2012, s. 104.

${ }^{104}$ Dictionnaire encyclopédique Quillet, t. 1, Paris 1968, s. 589.

${ }^{105}$ B. Kochaniewicz, Teologia Arnolda z Villanova: między Biblia a polityka, , Ruch Biblijny i Liturgiczny", 64 (2011) nr 3, s. 256. 
w oparciu o podręczniki wymowy. Dzieła z zakresu ascetyki, mistyki, kazuistyki oraz opisy ceremonii kościelnych były pomocą w innych kierunkach działalności duszpasterskiej. Niewielka grupa książek o tematyce świeckiej, ograniczająca się do klasycznej poezji i prozy łacińskiej, historiografii miała służyć zaspokajaniu różnorakich zainteresowań naukowych i kulturalnych wykształconych zakonników. Piśmiennictwo medyczne było zapewne pomocne w opiece nad chorującymi członkami domu zakonnego i okolicznej ludności. Księgozbiór miał zatem funkcjonalny charakter i zapewne dobrze spełniał swoje podstawowe zadania, dzięki czemu pozytywnie wpływał na formację intelektualną i duchową nie tylko zakonników, ale i laikatu.

\section{REFERENCES / BIBLIOGRAFIA}

\section{Źródła}

Archiwum OO. Dominikanów w Krakowie sygn. I.c.III 76/252. Teka wileńska.

\section{Opracowania}

Andrzejewski Roman, Cyceron, w: Encyklopedia katolicka, t. 3, red. R. Łukaszyk, L. Bieńkowski, F. Gryglewicz, Lublin 1979, kol. 677-678.

Anielski Wojciech, Clichtove Josse, w: Encyklopedia katolicka, t. 3, red. R. Łukaszyk, L. Bieńkowski, F. Gryglewicz, Lublin 1979, kol. 511-512.

Biographisch-bibliographisches Kirchenlexikon, Bd. 1, Hamm 1990.

Bartoszewski Konrad, Eyb Albrecht, w: Encyklopedia katolicka, t. 4, red. R. Łukaszyk, L. Bieńkowski, F. Gryglewicz, Lublin 1984, kol. 1475.

Barycz Henryk, Jakub Górski, w: Polski Stownik Biograficzny, t. 8, red. K. Lepszy, Wrocław 1959/1960, s. 438-440.

Barycz Henryk, Jan Maczyński, leksykograf polski XVI wieku, „Reformacja w Polsce”, 3 (1924) s. 218-255.

Barycz Henryk, Życie i twórczość Macieja z Miechowa. Pochodzenie, studia, podróże, w: Maciej z Miechowa 1457-1523. Historyk, geograf, lekarz i organizator nauki, Wrocław 1960, s. 15-74.

Bazielich Antoni, Dionizy Kartuz, w: Encyklopedia katolicka, t. 3, red. R. Łukaszyk, L. Bieńkowski, F. Gryglewicz, Lublin 1979, kol. 1339-1340.

Bieńkowska Barbara, Inwentarze księgozbiorów prywatnych jako źródlo do badań nad dziejami czytelnictwa, „Studia o Książce” 18 (1989) s. 65-75.

Biographish-bibliographisches Kirchenlexikon, t. 2, Hamm 1990.

Bogajewicz Stanisław Antoni, Rogalski Andrzej, Jan XXI, w: Encyklopedia katolicka, t. 7, red. S. Wielgus, Lublin 1997, kol. 831-833.

Brzozowski Mieczysław, Teoria kaznodziejstwa (wiek XVI-XVIII), w: Dzieje teologii katolickiej w Polsce, red. M. Rechowicz, t. 2, cz. 1: Od Odrodzenia do Oświecenia, Lublin 1975, s. 361-428.

Daniluk Mirosław, Baroniusz Marcin, w: Encyklopedia katolicka, t. 2, red. F. Gryglewicz, R. Łukaszyk, Z. Sułowski, Lublin 1976, kol. 62. 
Daniluk Mirosław, Hoffmeister Johann, w: Encyklopedia katolicka, t. 6, red. J. Walkusz, Lublin 1993, kol. 1109.

Daniluk Mirosław, Jan z Fryburga, w: Encyklopedia katolicka, t. 7, red. S. Wielgus, Lublin 1997, kol. 891.

Dictionnaire encyclopédique Quillet, t. 1, Paris 1968.

Dictionaire d'histoire et de geographie ecclesiastiques, t. 6, Paris 1932.

Długosz Józef, Biblioteka klasztoru karmelitów bosych w Wiśniczu (1630-1649), „Archiwa, Biblioteki i Muzea Kościelne”, 13 (1966) s. 132-162.

Drączkowski Franciszek, Epifaniusz, w: Encyklopedia katolicka, t. 4, red. R. Łukaszyk, L. Bieńkowski, F. Gryglewicz, Lublin 1984, kol. 1021-1023.

Drączkowski Franciszek, Euzebiusz z Cezarei, w: Encyklopedia katolicka, t. 4, red. R. Łukaszyk, L. Bieńkowski, F. Gryglewicz, Lublin 1984, kol. 1351-1352.

Drączkowski Franciszek, Grzegorz z Nazjanzu, w: Encyklopedia katolicka, t. 6, red. J. Walkusz, Lublin 1993, kol. 313-316.

Drączkowski Franciszek, Jan Chryzostom, w: Encyklopedia Katolicka, t. 7, red. S. Wielgus, Lublin 1997, kol. 799-769.

Duchniewski Jerzy, Calepio, Calepino Ambrogio, w: Encyklopedia katolicka, t. 2, red. F. Gryglewicz, R. Łukaszyk, Z. Sułowski, Lublin 1976, kol. 1278-1279.

Enciclopedia ecclesiastica, vol. 3, 5, Milano 1949-1952.

Encyklopedia Kościelna, t. 5, red. M. Nowodworski, Warszawa 1874.

Encyklopedia Kościoła, red. F.L. Cross, E.A. Livingstone, t. 1-2, Warszawa 2004.

Florkowski Eugeniusz, Atanazy Wielki, w: Encyklopedia katolicka, t. 1, red. F. Gryglewicz, R. Łukaszyk, Z. Sułowski, Lublin 1973, kol. 1026-1029.

Fros Henryk, Aniot Carletti z Chivasso, w: Encyklopedia katolicka, t. 1. red. F. Gryglewicz, R. Łukaszyk, Z. Sułowski, Lublin 1973, kol 613.

Gołębiowski Franciszek, Geiger Johannes, w: Encyklopedia katolicka, t. 5, red. L. Bieńkowski, Lublin 1989, kol. 930.

Grodziska-Ożóg Karolina, Marcin Polak i jego twórczość, „Nasza Przeszłość”, 58 (1983) s. $169-201$.

Hajdukiewicz Leszek, Wstęp, w: Pliniusz, Historia naturalna (wybór), Wrocław 1961, s. I-LXXVIII.

Janeczek Stanisław, Hugon ze Świętego Wiktora, w: Encyklopedia katolicka, t. 6, red. J. Walkusz, Lublin 1993, kol. 1292.

Jastrzębski Ambroży, Fabiani Andrea, w: Encyklopedia katolicka, t. 5, red. L. Bieńkowski, Lublin 1989, kol. 5.

Kardynat Stanisław Hozjusz (1504-1579): osoba, myśl, dzieło, czasy, znaczenie, red. S. Archemczyk, J. Guzowski, J. Jezierski, Olsztyn 2005.

Kędziora Stanisław, Misiurek Jerzy, Bernard z Clairvaux, w: Encyklopedia katolicka, t. 2, red. F. Gryglewicz, R. Łukaszyk, Z. Sułowski, Lublin 1976, kol. 301-302.

Klemensiewicz Zenon, O Janie Mączyńskim w czterechsetlecie jego dzieła, „Język Polski”, 44 (1964) nr 2, s. 65-75.

Kłoczowski Jerzy, Brygida Szwedzka, w: Encyklopedia katolicka, t. 2, red. F. Gryglewicz, R. Łukaszyk, Z. Sułowski, Lublin 1976, kol. 1115-1116.

Kochaniewicz Bogusław, Teologia Arnolda z Villanova: między Biblia a polityka, , Ruch Biblijny i Liturgiczny", 64 (2011) nr 3, s. 255-266.

Kosiński Józef Adam, Biblioteka konwentu dominikanów w Sieradzu na przełomie XVI i XVII wieku, w: Studia nad historia dominikanów w Polsce, red. J. Kłoczowski, t. 2, Wrocław 1975, s. 292-404. 
Krąpiec Mieczysław, Arystoteles, w: Encyklopedia katolicka, t. 1, red. F. Gryglewicz, R. Łukaszyk, Z. Sułowski, Lublin 1973, kol. 962-967.

Kumaniecki Kazimierz, Cyceron i jego współcześni, Warszawa 1989.

Kurdziałek Marian, Albert Wielki, w: Encyklopedia katolicka, t. 1, red. F. Gryglewicz, R. Łukaszyk, Z. Sułowski, Lublin 1973, kol. 301-302.

Kurdziałek Marian, Bartłomiej Anglik, w: Encyklopedia katolicka, t. 2, red. F. Gryglewicz, R. Łukaszyk, Z. Sułowski, Lublin 1976, kol. 75.

Lexikon für Theologie und Kirche, Bd. 3, 8, Freiburg im Breisgau 1959-1963.

Lewicki Jan, Bernardyn z Busti, w: Encyklopedia katolicka, t. 2, red. F. Gryglewicz, R. Łukaszyk, Z. Sułowski, Lublin 1976, kol. 312.

Longosz Stanisław, Kasjodor, w: Encyklopedia katolicka, t. 8, red. A. Szostek, Lublin 2000, kol. 946-949.

Małunowiczówna Leokadia, Ambroży, w: Encyklopedia katolicka, t. 1, red. F. Gryglewicz, R. Łukaszyk, Z. Sułowski, Lublin 1973, kol. 411-415.

Migoń Krzysztof, Bibliologia - nauka o kulturze książk, w: Encyklopedia ksiażki, red. A. Żbikowska-Migoń i M. Skalska-Zlat, t. 1, Eseje $A$-J, Wrocław 2017, s. 23-32.

Migoń Krzysztof, Dawne katalogi biblioteczne jako źródło wiedzy o kulturze książki, „Roczniki Biblioteczne”, 49 (2005) s. 301-310.

Miławicki Marek, Inwentarze i spisy bibliotek klasztorów dominikańskich skasowanych $w$ guberniach zachodnich Cesarstwa Rosyjskiego w XIX w. Stan źródet i miejsce ich przechowywania, „Hereditas Monasteriorum”, 1 (2012) s. 141-172.

Misiurek Jerzy, Augustyn, w: Encyklopedia katolicka, t. 1, red. F. Gryglewicz, R. Łukaszyk, Z. Sułowski, Lublin 1973, kol. 1087-1095.

Misiurek Jerzy, Hozjusz Stanisław, w: Encyklopedia katolicka, t. 6, red. J. Walkusz, Lublin 1993 kol. 1258.

Moskal Piotr, Kajetan, w: Encyklopedia katolicka, t. 8, red. B. Migut, Lublin 2000, kol. 338-339.

Myszor Wincenty, Cyprian, w: Encyklopedia katolicka, t. 3, red. R. Łukaszczyk, L. Bieńkowski, F. Gryglewicz, Lublin 1979, kol. 690-693.

Niedziela Maurycy Lucjan, Charakterystyka biblioteki klasztoru Dominikanów w Borku Starym w XVII i XVIII wieku, „Śląski Kwartalnik Historyczny. Sobótka”, 51 (1996) s. 196-203.

Piotr Skarga, w: Encyklopedia wiedzy o jezuitach na ziemiach Polski i Litwy 1564-1995, oprac. L. Grzebień SJ, Kraków 2004, s. 619-620.

Plezia Marian, Wstęp, w: Jakub de Voragine. Złota legenda. Wybór, Warszawa 1955, s. I-LXXXVII.

Podręczna encyklopedia kościelna, t. 29-30, red. S. Gall, Warszawa 1913.

Pociecha Władysław, Decjusz Jost Ludwik, w: Polski Słownik Biograficzny, t. 5, red. W. Konopczyński, Kraków 1939/1946, s. 42-45.

Przekop Edmund, Durand Guillaume Starszy, w: Encyklopedia katolicka, t. 4, red. R. Łukaszyk, L. Bieńkowski, F. Gryglewicz, Lublin 1984, kol. 368-369.

Rosik Seweryn, Grzegorz I Wielki, w: Encyklopedia katolicka, t. 6, red. J. Walkusz, Lublin 1993, kol. 324-327.

Rusiecki Mieczysław, Katechizm, w: Encyklopedia katolicka, t. 8, red. A. Szostek, Lublin 2000, kol. 1038-1047.

Rybczyński Henryk, Bernard z Botony, w: Encyklopedia katolicka, t. 2, red. F. Gryglewicz, R. Łukaszyk, Z. Sułowski, Lublin 1976, kol. 300. 
Skoczek Józef, Inwentarze biblioteczne jako źródło do dziejów kultury Polski epoki Odrodzenia, „Sprawozdania Poznańskiego Towarzystwa Przyjaciół Nauk”, 21 (1957) s. $267-270$.

Słowiński Jan, Rozwój pisma łacińskiego w Polsce w XVI-XVIII wieku. Studium paleograficzne, Lublin 1992.

Słownik kultury antycznej, red. R. Kulesza, Warszawa 2012.

Smoleński Stanisław, Adam Szkot, w: Encyklopedia katolicka, t. 1, red. F. Gryglewicz, R. Łukaszyk, Z. Sułowski, Lublin 1973, kol. 73.

Sokołowski Edward, Alfons de Castro, w: Encyklopedia katolicka, t. 1, red. F. Gryglewicz, R. Łukaszyk, Z. Sułowski, Lublin 1973, kol. 258.

Stanula Emil, Hieronim, w: Encyklopedia Katolicka, t. 6, red. J. Walkusz, Lublin 1993, kol. 851-853.

Starowieyski Marek, Beda Czcigodny, w: Encyklopedia katolicka, t. 2, red. F. Gryglewicz, R. Łukaszyk, Z. Sułowski, Lublin 1976, kol. 171.

Swastek Józef, Erazm z Rotterdamu, w: Encyklopedia katolicka, t. 4, red. R. Łukaszyk, L. Bieńkowski, F. Gryglewicz, Lublin 1984, kol. 1062-1063.

Szostek Irena, Biblioteka dominikanów we Wrocławiu (1226-1810), w: Studia nad historia dominikanów w Polsce, red. J. Kłoczowski, t. 2, Wrocław 1975, s. 409-446.

Szymik Stanisław, Mikołaj z Liry, w: Encyklopedia katolicka, t. 12, red. S. Wilk, Lublin 2008, kol. 1005-1006.

Świętochowski Robert, Biblioteka OO. Dominikanów w Krakowie, „Archiwa, Biblioteki i Muzea Kościelne", 33 (1976) s. 299-311.

Świeżawski Stefan, Studia z myśli późnego średniowiecza, Warszawa 1998.

Świeżawski Stefan, Święty Tomasz na nowo odczytany, Poznań 2002.

Tazbir Janusz, Skarga Piotr, w: Polski Słownik Biograficzny, t. 37, red. H. Markiewicz, Warszawa 1997, s. 35-43.

Torell Jean-Pierre, Tomasz z Akwinu - człowiek i dzieło, Kęty-Warszawa 2008.

Trapé Agostino, Święty Augustyn - człowiek, duszpasterz, mistyk, Warszawa 1987.

Vetulani Adam, Corpus iuris canonici, w: Encyklopedia katolicka, t. 3, red. R. Łukaszczyk, L. Bieńkowski, F. Gryglewicz, Lublin 1979, kol. 598-599.

Warda Kazimierz, Inwentarze bibliotek klasztornych jako źródło do dziejów ksiązki polskiej w XIX w., „Studia o Książce”, 15 (1985) s. 115-123.

Waszkinel Romuald, Caprelous Jean, w: Encyklopedia Katolicka, t. 2, red. F. Gryglewicz, R. Łukaszyk, Z. Sułowski, Lublin 1976, kol. 1322-1323.

Wawro Józef, Aleksander z Hales, w: Encyklopedia katolicka, t. 1, red. F. Gryglewicz, R. Łukaszyk, Z. Sułowski, Lublin 1973, kol. 335-340.

Wawrzyniak Franciszek, Epiktet z Hierapolis, w: Encyklopedia katolicka, t. 4, red. R. Łukaszyk, L. Bieńkowski, F. Gryglewicz, Lublin 1984, kol. 1031-1032.

Wielgus Stanisław, Gerson Jan, w: Encyklopedia katolicka, t. 5, red. L. Bieńkowski, Lublin 1989, kol. 1118-1119.

Witek Stanisław, Bartłomiej z San Concordio, w: Encyklopedia katolicka, t. 2, red. F. Gryglewicz, R. Łukaszyk, Z. Sułowski, Lublin 1976, kol. 81.

Wojtyska Henryk, Bernard z Luksemburga, w: Encyklopedia katolicka, t. 2, red. F. Gryglewicz, R. Łukaszyk, Z. Sułowski, Lublin 1976, kol. 308.

Wojtyska Henryk, Eck Johann, w: Encyklopedia katolicka, t. 4, red. R. Łukaszyk, L. Bieńkowski, F. Gryglewicz, Lublin 1984, kol. 648-649.

Wójcik Edwin, Piotr Lombard, w: Encyklopedia katolicka, t. 15, red. S. Wilk, Lublin 2011, kol. 678-681. 
Wysocki Marcin, Tertulian, w: Encyklopedia katolicka, t. 19, red. S. Wilk, Lublin 2013, kol. 731-735.

Zawadzka Krystyna, Biblioteka klasztoru dominikanów we Wrocławiu (1226-1810), w: Studia nad historia dominikanów w Polsce, red. J. Kłoczowski, t. 2, Wrocław 1975, s. 290-362.

Zbicia Józef, Jakub de Voragine, w: Encyklopedia katolicka, t. 7, red. S. Wielgus, Lublin 1997, kol. 713-714.

Zieliński Edward, Bonawentura, w: Encyklopedia katolicka, t. 2, red. F. Gryglewicz, R. Łukaszyk, Z. Sułowski, Lublin 1976, kol. 780-785.

\title{
Netografia
}

https://www.worldcat.org (dostęp: 01.05 - 31.11.2019)

\section{THE INTELLECTUAL AND SPIRITUAL CULTURE OF THE DOMINICANS OF VILNIUS IN THE LIGHT OF THE LIBRARY INVENTORY FROM THE FIRST HALF OF THE 17TH CENTURY}

\begin{abstract}
The inventory of the Vilnius Dominican library from the first half of the 17th century records 506 publishing items. These include prints published in the 15 th, 16th and a small number from the 17th century. They were printed mainly by foreign publishing houses: Italian, French, German, Dutch and Swiss. In terms of content, they represent all areas of human knowledge at the time, and their number in individual sections reflects the demand of the Dominicans of Vilnius for specific literature that allowed them to properly fulfil their tasks towards their own congregation, monastery and external environment.
\end{abstract}

Keywords: book; library; inventory; Dominicans; Vilnius; 17th century 